\title{
Mediatizing Gaza: An Introduction
}

NOUR SHREIM, Independent Scholar

SIMON DAWES, Université Paul Valéry - Montpellier 3, France

\begin{abstract}
This full-length article introduces a special issue on the mediatization of Gaza. Beginning with a discussion on the 'remarkable' debate that took place on the MeCCSA mailing list during the Israeli bombardment of Gaza in July-August 2014, the article goes on to consider the role of the media in the conflict, and the relation between media and war, more generally. The article provides an overview of recent events in Gaza, the critique of media coverage of the conflict and recent literature on mediatization theory, before summarising the contents of this special issue of Networking Knowledge. The issue features articles on media coverage of Gaza by BBC World, the Jerusalem Post and Haaretz; the use of social media by the Palestine Solidarity Movement and young adult Palestinian refugees in Lebanon; critical documentary photographs of 'unspectacular' violence; and data visualisations of audio and visual tweets during the 2014 assault on Gaza. It closes with an interview with Helga Tawil-Souri on the 'digital occupation' of Gaza.
\end{abstract}

\section{KEYWORDS}

Gaza; Mediatization; Palestinan-Israeli Conflict; occupation 
During the Israeli bombardment of Gaza in July and August in 2014, an interesting debate took place on the MeCCSA mailing list, sparked off by a blog post from Michael Chanan (2014a). This "remarkable discussion" (Chanan 2014b) began as a series of protests at the suffering of the many Palestinian victims, the injustice of Israeli actions, and the frustratingly disappointing mainstream media coverage. A dissenting voice soon entered the discussion, however, in the form of someone subsequently identified as a former Political Communications advisor to Prime Minister Benjamin Netanyahu. Persistent in her efforts to put across what she called "the other side of the story", she was also persistent in making unsubstantiated claims and denying facts, while denouncing as propaganda the substantiated claims of others.

Tensions then arose among the other members of the list, between, on the one hand, those who either felt it their duty to engage in the debate or who couldn't refrain from expressing themselves, passionately and sometimes in the form of personal attacks, and those, on the other hand, who defended the "long distance propagandist's" (Chanan 2014b) right to express herself, and who reminded those who disagreed of their responsibility to respect that. The tensions continued to arise, as some members complained that they didn't appreciate their inboxes filling up with such messages, arguing that it was not the appropriate forum for such debates and announcing their wish to unsubscribe from the mailing list, whose Operations Manager eventually intervened to request that the discussion on the thread cease immediately and a "more appropriate discussion forum" be found. They, in turn, were reprimanded by other members who argued that engaging in such debate was the "raison d'etre of the list" (Chanan 2014b), and who criticised their colleagues for trying to silence the debate, or for being media scholars who lacked the media literacy required to unsubscribe from the list without having to publicise their requests.

An alternative forum was, nevertheless, set up by list member Gabriel Moreno, originally using the Socializer pod to connect with users under the hashtag \#BehindTheNewsFromGaza on the Diaspora social network, then eventually in the more accessible form of a Facebook group, Mediating Gaza ${ }^{1}$. From one social media to another.

While most research demonstrates an imbalance, favouring the Israeli perspective, in the mainstream reporting of the Arab-Israeli conflict, digital and social media have offered an opportunity for this to be rebalanced. The adoption of particular hashtags (\#GazaUnderAttack) on Twitter, websites launched by diasporic Palestinians (Electronic Intifada), video cameras given out to Palestinians to document settler violence (B'Tselem), the creation of local news networks (Ma'an), and the emergence of grass-roots social media-based movements (Gaza Youth Breaks Out (GYBO), the Third Intifada Facebook group), demonstrate an increased awareness among Palestinians to try to effect change in different ways (Tawil-Souri, this issue). They have given Palestinians (inhabitants and refugees) and pro-Palestinians the chance to

\footnotetext{
${ }^{1}$ For a full digest of the discussion on multiple threads, go to http://www.meccsa.org.uk/resources/discussion-list/ and search under 'Behind the News from Gaza', or go to the digest made available by Michael Chanan: https://dl.dropboxusercontent.com/u/1933290/Gaza\%20The\%20Meccsa\%20Discussion\%20\% 28edited\%29.pdf
} 
express themselves and connect with each other, as well as representing the experience of civilians in Gaza, and criticism of Israel, to a global public that has perpetually been, heretofore, either misinformed or only partially informed about the conflict. This has led some to suggest that Israel is losing the '(social) media war' 2 .

Despite the rise of media activism from pro-Palestinians, however, the pressure exerted by pro-Israel groups and individuals on old media, and their influence on public opinion, continues to be well documented ${ }^{3}$. Similarly, reports of initiatives such as the "Hasbara war room" in Tel Aviv, in which hundreds of college students volunteer to "explain" the Israeli case through "comments, memes, video clips, images and explanatory graphics on Facebook and Twitter from dozens of computers" ${ }^{\prime 4}$, reveal a similarly well organised and strategic influence on social media networks.

However, although many around the world have been exposed to the pro-Palestinian perspective, perhaps for the first time, the personalised spaces of social media often lead to a 'personalisation of propaganda', whereby we are only exposed to what we already agree with, thus exacerbating the polarisation of debate ${ }^{5}$. Meanwhile, activists' hacking of the websites and social media accounts of (western) mainstream media outlets is becoming an increasingly commonplace occurrence ${ }^{6}$.

While the critique of mainstream news reporting and the social media counternarrative are important objects of social scientific research, however, they are not the only ways in which the conflict has been mediatized. The occupation and control over frequencies, the electro-magnetic field and the communications infrastructure in Palestine, as well as the increased use of "unmanned aerial reconnaissance and attack drones, remote-controlled machine guns, closed-circuit television, sonic imagery, gamma-radiation detectors, remote-controlled bulldozers and boats, electrified fences, among many other examples, are increasingly used for control and surveillance" (Tawil-Souri 2012, 27), particularly since formal military withdrawal from Gaza in 2005.

Nor does acknowledging the mediatization of Gaza suggest that the occupation is any less real or somehow demilitarised. On the contrary, some have even referred to Israel's "digital militarism" (Kuntsman \& Stein, 2015) and the "militarisation of (social) media" 7 , pointing to the Israeli military's use of social media as a public

\footnotetext{
${ }^{2}$ See: http://blogs.channel4.com/paul-mason-blog/impact-social-media-israelgazaconflict/1182

${ }^{3}$ See: https://www.opendemocracy.net/ourkingdom/peter-oborne-james-jones/pro-israellobby-in-britain-full-text\#m6

Or: https://www.opendemocracy.net/ourkingdom/hilary-aked/bbc-bias-reporting-on-israeland-palestinians

${ }^{4}$ See: http://www.nytimes.com/2014/07/16/world/middleeast/young-israelis-fight-hashtagbattle-to-defend-israelunderfire.html

${ }^{5}$ See: http://www.huffingtonpost.com/gilad-lotan/israel-gaza-war-social-networksdata b $5658557 . h t m l$

${ }^{6}$ See: http://www.breitbart.com/national-security/2014/08/18/pro-israel-hacker-causingchaos-on-pro-palestinian-sites/

Or

http://uk.reuters.com/article/2014/11/27/uk-syria-crisis-hack-idUKKCN0JB1H820141127

${ }^{7}$ See: http://mondoweiss.net/2014/07/israel-militarized-social
} 
relations platform and instrument of war. Rather, it turns attention to questions about the extent to which Israeli media technology is driven with the built-in intent of warfare (Tawil-Souri, this issue), and focuses on the ways in which the Israeli military has treated Gaza as a testing ground, and its inhabitants as guinea pigs, for their new military technologies.

Calling this issue 'Mediatizing Gaza' (rather than 'Mediating Gaza') highlights 'mediatization' as a process and as an increasingly significant aspect of the occupation of Gaza. It also foregrounds a dialectical approach to studying the relation between media and the occupation, acknowledging the complexity of relations that are the cause and effect of any particular moment of mediation.

In the next section, we provide an overview of the recent Israeli assault on Gaza in 2014, considering it briefly in historical context, and particularly in terms of the previous major assault in 2008-2009, and the general condition of military occupation. We then move on to a review of the literature critiquing the media coverage of the Arab-Israeli conflict, and to a discussion of the mediatization of war and the occupation of Gaza, before elaborating further our use of the 'mediatization' concept. This introduction to the special issue then ends with a brief summary of the articles.

\section{History}

The Gaza Strip, situated between Israel and Egypt, has for many years been a regular flashpoint in the 68-year Palestinian-Israeli conflict. In 2005, Israel pulled its troops and settlers out of Gaza, after it had occupied the strip during the 1967 Six Day War. Whilst Israel claims that the Disengagement Plan of 2005 is an effort to end the occupation, it still exercises 'exclusive authority' over Gaza's airspace and territorial waters, restricting the movement of people and goods into and out of the Strip (Roy 2007, 314).

After more than eight years of tight restrictions (since 2007), even after Israel eased its sanctions on non-military goods in 2011, the blockade on Gaza, often referred to as 'collective punishment' (BBC News 2010; Amnesty International 2010), continues to take a heavy toll on Gaza's civilian population, with many vital and basic goods prevented from being exported or imported. Rampant levels of poverty and an intolerable unemployment rate in Gaza has led more than 70 percent of the population to depend on human aid (Amnesty International 2010). According to the UN, more than 30 percent of Gaza's 'arable land and about 85 per cent of its fishing waters are totally or partially inaccessible due to the Israeli blockade' (Al-Jazeera 2011). As a result, underground tunnels have been, and still are, Gaza's main lifeline to Egypt and the rest of the world (Al-Jazeera 2011).

\section{8-2009 Gaza War-Operation Cast Lead}

Despite the warnings, the timing and scale of the assaults on Gaza came as a surprise to many of its residents. On December 27, 2008 at 11.30 a.m., Israel launched dozens of air raids across Gaza 'using F-16 fighter jets, apache helicopters and unmanned 
drones' (Philo and Berry 2011, 141). The timing of this operation, codenamed 'Operation Cast Lead', was severely criticised given the most intense phase of the air raids took place mid-morning, which meant many official buildings and schools were full (Percival 2008). As part of Israel's assaults, it quickly sealed off all crossing points to Gaza preventing journalists, humanitarian aid workers and human rights monitories from entry (Philo and Berry 2011, 141). The first day, which was referred to as 'one of the bloodiest days for decades in the long-running Israeli-Palestinian conflict' (Percival 2008), saw at least 225 Gazans killed and more than 700 wounded, with reports indicating that 'some of the missiles struck densely populated areas as children were leaving school. Parents rushed into the streets to search for them' (ibid.). The attacks, led to immediate responses from the international community; some, such as the European Union, called for an immediate ceasefire and for the 'reopening of all checkpoints and the immediate resumption of fuel and humanitarian aid deliveries' (European Jewish Press, 28 December 2008, cited in Philo and Berry 2011, 141); others, such as the United States and Great Britain, refused to call for a ceasefire but condemned Hamas and urged Israel to avoid civilian casualties (The Times 28 December 2008, cited in Philo and Berry 2011, 141). The following three weeks saw Israel attacking large areas of Gaza, mainly targeting:

The parliament building, the ministers of Foreign Affairs, Labour, Housing and Construction, Finance and Justice, UN food and medicine compounds, civilian apartment blocks, a university, television stations, newspaper offices, a prison, police stations. mosques, schools, kindergartens, hospitals, ambulances, water treatment plants, water wells, sewage works, factories, markets, workshops, food processing plants, orchards, a fish farm, agricultural crops, farm animals and greenhouses (Amnesty International 2009; United Nations 2009a, cited in Philo and Berry 2011, 142).

Hamas, on the other hand, continued to launch rockets from Gaza into the Southern parts of Israel. Using Chinese-manufactured WS-1E rockets, which have a range of more than $40 \mathrm{~km}$, Palestinian rockets were able, for the first time, to reach cities such as Ashdod, Beersheba and Gedera (Globalsecurity 2009, cited in Philo and Berry 2011, 142).

During the 22-day Israeli offensive on Gaza, three Israeli civilians were killed and four others were seriously wounded; ten Israeli soldiers were also killed, four of whom were reported to have died in 'friendly fire' incidents, and at least 100 were wounded (Philo and Berry 2011, 142). Far more Palestinians, including women and children, were killed, but the exact figures have been disputed. The number of Palestinians killed ranged from 1,166, according to the Israeli army (89 minors) (Jerusalem Post, 26 March 2009 in ibid.), 1,385 according to B'Tselem (313 minors) (2009b in Philo and Berry 2011, 142), and 1, 314 according to the Ministry of Health in Gaza (412 minors) (Bell 2009).

Like Operation Protective Edge, Israel has consistently argued that it undertook its military operation to emphasise the primacy of its security, demanding the end of rocket attacks on the southern part of the country, and efficient measures to be undertaken against arms smuggling from Egypt into Gaza. In addition, Israel also hoped to unconditionally release Sgt. Shalit from Hamas prisons, captured in 2006. Meanwhile, Hamas continued to call for the opening of all crossing into and out of 
Gaza with Egypt and Israel, and the end of 40 years of occupation. Israel had maintained the blockade on Gaza after the ceasefire agreement came into effect, preventing exports and drastically limiting the number of imported goods into the Strip.

Human rights groups accused both parties of violating International Humanitarian Law. Amnesty International accused Palestinians of launching rocket attacks at Israeli civilians in the line of fire and widening the circle of fear amongst Israelis. In terms of its conduct in endangering Palestinian civilians, the organisation accused Palestinian groups of rocket launching, fighting and storing weapons in residential areas. Hamas and other Palestinian groups were also held responsible for the safety of Gaza's population (Amnesty International 2009). Israel, on the other hand, was accused of committing war crimes; such practices included: targeted air-strikes against buildings and people, and targeting 'anything that moves'; the indiscriminate use of heavy artillery in densely populated urban areas; indiscriminate attacks using mortar shells, white phosphorus and flechettes; attacking and obstructing medical workers; the targeting of persons trying to convey civilian status using white flags; and denying humanitarian access and ruining a fragile economy; using Palestinians, including Palestinian children, as 'human shields' (Amnesty International 2009).

\section{Operation Protective Edge - 2014 Gaza War Gaza}

On July 8 2014, in response to the abduction and death of three Israeli teenagers in the West Bank, the IDF (Israel Defence Forces) launched 'Operation Protective Edge', which eventually spiralled into a ground invasion. A ceasefire commenced on August 27 - after 50 days of intense fighting - with the death toll standing at approximately 2,100 Palestinians, the vast majority of which $(90 \%)$ were civilian non-combatants, and $20 \%$ of which were children; as well as 72 Israelis - all of whom but 6 were soldiers (The Guardian 2014).

Gilad Shaar, Eyal Yifrah, and Naftali Frenkel disappeared on June 10 2014, while in the West Bank. Israeli Prime Minister Benjamin Netanyahu blamed Hamas members for the kidnapping of the boys, which led to a crackdown on the group in the West Bank (BBC 2014b). Hamas initially denied being behind the killings but later, one of its political leaders said members had carried it out (BBC 2014a). Israel conducted a massive manhunt in the Palestinian territory that ended on June $30^{\text {th }}$ when the three boys were found dead, apparently executed (BBC 2014b). Subsequent reports suggested that Israel was aware that the boys were dead when the search began, but used the manhunt as an excuse to arrest a large number of Hamas operatives as a response to the killings (Goldberg 2014). Following the arrests, Israel also launched a limited bombing campaign in Gaza against Hamas targets, justified by Israel as retaliation for the murder of the three boys.

Tensions rose further after the suspected revenge killing of a Palestinian teenager (apparently burnt to death), named Mohammad Abu Khdeir, in Jerusalem on July 2. The attacks, termed as 'nationalistic' by some Israelis, saw the arrest of six Jewish suspects. Following a string of violence against Palestinians by Israeli settlers, a video surfaced showing Tariq Abu Khdeir, Mohammad's 15-year-old cousin, getting 
brutally beaten while detained by Israeli police after a Palestinian demonstration in East Jerusalem (Grim 2014).

As a response to the Khdeir boys, the bombings in Gaza, and the clamp-down on the West Bank during the search for the murdered boys, Hamas launched 40 rockets on Israel on July 7, for which it claimed responsibility for the first time since 2012 (Erlanger and Kershner 2014). Israel responded by launching Operation Protective Edge, as part of what Netanyahu said was an effort to make Hamas 'pay a heavy price' (Sobelman 2014). On 17 July, Israel invaded Gaza - its first ground invasion since Operation Cast Lead in 2009 - that it said was aimed at stopping rocket attacks and destroying the tunnels Hamas built from Gaza into Israel (BBC, 2014a). Following some days of intense fighting, which left more than 10,000 Palestinians injured - many severely wounded - and huge parts of the Strip in destruction, which made more than a quarter of Gazans displaced (United Nations, 2014), Israel withdrew its troops on August 5. On August 26, an open-ended ceasefire was announced.

Israel's main declared aim was to end the rocket fire from Gaza and restore peace and safety for its citizens. As well as destroying Hamas's tunnels - of which it claims it destroyed 32 - Israel wants Gaza to be 'demilitarised' (BBC 2014a). Hamas, on the other hand, want an immediate end to the 7-year blockade of Gaza, an end to the Israeli "aggression" in the West Bank, Jerusalem and Gaza, and the release of prisoners who were freed in exchange for Gilad Shalit in 2011, but who were later rearrested (ibid.).

The intense bombing of houses and apartment buildings left approximately $30 \%$ of the Gazan population homeless. The United Nations Office for the Coordination of Humanitarian Affairs (OCHA) revealed that over 273,000 Palestinians in the Gaza Strip had been displaced as of 31 July 2014, the majority of which were taking refuge in 88 UNRWA (United Nations Relief and Works Agency) schools. A halt or reduction in water and power supplies affected a total of 1.8 million people. Seven weeks of bombardment destroyed over 17,000 homes, 138 schools, 26 health facilities, large areas of cropland and agricultural infrastructure. However, a recent report by the World Bank found that the economic situation in Gaza was declining even before the Israeli Offensive on Gaza in Summer 2014, with over 70 percent of Gazans living on less than $\$ 2$ a day (Al-Jazeera English 2014). The report indicates that the recent attacks on Gaza only added to the already dire situation in the Strip. As such, over two thirds of Gaza's population were regularly receiving food assistance even before the attacks started, with the number rising by 700,000 during the summer (FAO 2014).

President Mahmoud Abbas has accused Israel of committing "genocide" (BBC 2014a) and the UN is investigating human rights violations on both sides of the conflict (The Guardian 2014). A report released by Amnesty International stated that Israel has displayed "callous indifference" in their attacks on family homes in densely populated areas in the strip, and accused Israel and Hamas of war crimes in some cases (Amnesty International 2014). The report documents eight cases in which the IDF have launched attacks on homes in Gaza without warning, killing "at least 104 civilians including 64 children", sometimes "killing entire families" (ibid.). The report continues that while military targets were identified in some cases, "the devastation to 
civilian lives...was clearly disproportionate" (The Guardian 2014). Findings of the report were rejected by Israel's foreign ministry; saying that Amnesty "ignores documented war crimes perpetrated by Hamas" (ibid.). Israel insists that the homes it bombed belonged to senior Hamas members, and were used as 'command centres' to co-ordinate rocks attacks. It accuses 'militants' of deliberately firing rockets from civilian areas such as homes, schools and hospitals - a claim that Hamas rejects (ibid.). However, the report also accused "Palestinian armed groups [of committing] war crimes, firing thousands of indiscriminate rockets into Israel killing six civilians including one child" (The Guardian 2014).

\section{Media Coverage of the Arab-Israeli conflict}

Just like the historical background of the Arab-Israeli conflict, its media coverage has been a matter of extreme controversy and sensitivity, most noticeably with regards to international broadcasters and media academics. In fact, an array of scholarly literature exists which attempts to examine media bias for or against one side of the conflict or the other. In recent years, scholarly research conducted in Europe, examining the media coverage of the conflict, has received considerable attention (e.g. Barkho 2010, 2011; Barkho and Richardson 2010; Gaber, Seymour and Thomas 2009; Loughborough University Communications Research Centre 2006; Philo and Berry 2004, 2006, 2011; Richardson 2004; Richardson and Barkho 2009).

Empirical research into the media content of the conflict demonstrates varied discrepancies in which the Palestinians and the Israelis are depicted in the news. Generally speaking, nearly all studies reveal an imbalance in reporting favouring the Israeli perspective. Most prominent in this regard are Philo and Berry's extensive studies $(2004,2011)$ of TV news coverage of the Al-Aqsa Palestinian Intifada and later the 2008-09 Gaza offensive. Between September 2000 and April 2002, the Glasgow Media Group collected and analysed nearly two hundred news bulletins from BBC and ITV news and interviewed almost eight hundred individuals in Britain, Germany and the United States to examine their levels of knowledge and understanding of the conflict. One of the most significant findings that emerged from the study, suggested that in the period of the Al-Aqsa Intifada, "the coverage as a whole was permeated with images, descriptions and references to conflict and violence including riots, mobs, stone-throwing, stabbing, shooting, kidnapping, protests and military attacks' (Philo and Berry 2004, 102). The findings further indicate that many of the focus group participants were confused about the history, origins and underlying political dimensions of the conflict (Philo and Berry 2006, 199). In this regard, the authors strongly propose that 'the gaps in public knowledge' are directly related 'to a lack of context and explanation of key issues in news bulletins' (Philo and Berry 2006, 199).

Another crucial finding to emerge from the study indicates that Israeli perspectives on the conflict were featured more prominently than those of the Palestinians (Philo and Berry 2006, 202). The Israeli military perspective, for example, that Israel is fighting a 'War on Terror', was heavily featured, while the Palestinian viewpoint that they are 'resisting an illegal military occupation' was almost continuously excluded from the coverage (ibid.). They also found very few references to the military nature of the 
occupation, its social consequences on the Palestinians, the exploitation of Palestinian land and water resources, the strategic role of Israeli settlements, or explanations about how the Palestinians became refugees (ibid, 202-3). Also, the large number of United Nations resolutions condemning the occupation was rarely touched upon (ibid, 202). Finally, the authors depicted large disparities in the language used to label acts and actors from both sides. Phrases such as 'mass murder', 'atrocity', 'brutal murder', 'lynching' and 'savage cold blooded killing' were only used to describe Israeli casualties perpetrated by Palestinian 'terrorists' (ibid, 204). Overall, Israelis were continuously presented as 'retaliating' or 'responding' to trouble and violence 'initiated' by Palestinians (ibid, 203-04).

Building on this research, the second edition of the seminal Bad News from Israel, titled More Bad News from Israel, includes studies on television news coverage of the Israeli attack on Gaza in December 2008 and on the Gaza flotilla in 2010. In terms of motivations and rationale, Philo and Berry (2011) argue that the Israeli narrative dominated the news during the Gaza conflict. The Israeli position, that they were forced to respond to unwarranted rocket attacks by Hamas, often excluded Hamas's reasons for the conflict, which are mostly to resist an illegitimate military occupation by Israel since 1967. Instead, the Israeli narrative that began in 2005, when Israel withdrew its Jewish settlements from Gaza, depicted Palestinians as unwilling to reconcile and build a new state, and more interested in killing Jews (ibid, 336-7). Themes such 'ending the rockets', the 'need for security', an end to 'the smuggling of weapons' and the need to 'hit Hamas' dominated the news content. Explanatory statements issued by Palestinians/Hamas constituted a much lower total (ibid, 341). The authors argue that Israeli actions are still represented as 'responses' to violence perpetrated by the Palestinians (ibid, 342), depicting the Israeli attack as being directed only at Hamas and not the Palestinian civilian population (ibid, 343). The view that 'the Palestinians are a people in a war of national liberation, trying to throw off an occupying force' was largely absent from the coverage (ibid, 346).

The publication of this research attracted a corpus of scholarly attention. Wolfsfeld (2006) in his review of Bad News from Israel, for example, described the study as 'highly suspect' (p. 476). He argues that for a research project to be 'convincing' in this area 'it would have to employ extremely meticulous methods in order to overcome any suspicions that the authors simply found what they were looking for' (ibid.). The content analysis employed in the study, he affirms, consists, for the most part, of 'choosing examples from the coverage that illustrates the authors' points' (ibid.).

The $\mathrm{BBC}$, however, has been subject to intense scrutiny in its coverage of the conflict, with mounting studies accusing the Corporation of being more favourable to Israel. In 2005, the BBC Board of Governors visibly engaged with such critical assessment, and assigned an independent panel to evaluate these claims. The panel commissioned scholars from Loughborough University to undertake an extensive content analysis of the BBC's coverage of the conflict over a six-month period (Loughborough University Communications Research Centre 2006). Although the report refrains from making any normative claims about the degree of impartiality of the coverage, it provides similar findings to that of Philo and Berry (2004). The report concluded that the majority of news reports lacked sufficient historical context, rarely touched upon the ongoing annexation of land in East Jerusalem and the West Bank, and was 
imbalanced in its reporting of fatalities -with Israeli deaths attracting more coverage than Palestinian ones (Loughborough University 2006, 87).

Richardson and Barkho (2009) propose that decades of covering the same conflict have had an impact on BBC's reporting. What they term 'the Middle East culture' obligates journalists and editors to follow a strict guideline of facts and terminology recommended by the BBC Governors' independent panel report on the impartiality of BBC's coverage of the conflict (BBC 2006, cited in Barkho 2008, 281). In October 2006, twenty-four such words were publicised from a long list of phrases, otherwise known only to the organisation (ibid.). This Middle East culture also includes the BBC's College of Journalism's online-module -Israel and the Palestinians - specially designed for journalists who intend to cover the region. Only those who manage to pass the module, complying with BBC's rules and principles, are able to report on the region. Finally, Richardson and Barkho state, 'This culture has deep roots in the organisation to the extent that at least four senior editors - called 'the four wise men'have to agree before a new 'softer' or 'harsher' lexical item can be used' (Richardson and Barkho 2009, 619).

The choice of vocabulary risks generating an imbalance in the social relations of power, and has the potential of characterising people in different ways (Barkho and Richardson 2010). The management of vocabulary, it is assumed, is capable of 'lexicalizing' and even 'standardizing' the social world (ibid.). BBC editors, such as Jeremy Bowen (Middle Eastern editor), maintain that the Middle East is 'the most complex and newsworthy place in the world' (Independent, 11 Dec 2006, cited in Barkho 2008, 282). Yet, when these discursive strategies are put into practice in avoiding the use of "emotional" or "judgmental" words such as "TERRORISTS" (unless attributed), the guidelines are shown to be inconsistent as they allow the use of lexical items which are no less excessive; operating, for the most part, in Israel's favour (Barkho and Richardson 2010). The authors, making clear that editors position themselves in trying to avoid the use of terminology favoured by one side of the dispute, give the examples of 'militants', 'extremists', 'Islamists' and 'fundamentalists' - harsh phrases used to describe Palestinians - as opposed to phrases such as 'settlements', 'settlers', 'Jerusalem' and 'territories' - praised by Israelis and rejected by Palestinians (Barkho and Richardson 2010). The Palestinians, it is argued, are discursively and socially disadvantaged in BBC's reporting. The authors, examining the 'visual and verbal rhetoric of $\mathrm{BBC}$ journalism' vis-à-vis the Palestinian-Israeli conflict, conclude that such measures are the basis of BBC's 'inequality' in reporting the conflict.

Barkho (2010) explains that, according to BBC journalists, the abbreviated version of facts and terminology has only complicated editorial tensions with regards to the coverage (p. 140). On the level of language, Barkho concludes, the BBC culture insists on a structural difference evidenced in the varying relations of "power, geography, ideology, media control, and technology' between the protagonists (2010, 141). Analysing the BBC's choice of vocabulary, on the lexical and syntactic levels and across the BBC's Arabic and English Services, Barkho demonstrates that there is an unequal division of power, control and status separating the protagonists (p. 140). On the lexical level, only one side (the Palestinian) is subjected to re-lexicalisation and over-lexicalisation. From a syntactic point of view, the corporation's Arabic Service demonstrates patterns 'which trivialize both the Palestinian and Israeli 
casualties, while the English service opts for patterns that undermine Palestinian casualties' (ibid.).

Barkho (2011), in a later publication, assesses the discursive and social paradigms adopted by Al-Jazeera English (AJE) in its coverage of the 2008-09 Gaza Conflict, and makes comparative references to that of the BBC. Proclaiming that both AJE and BBC broadcast in English, Barkho, nonetheless, suggests that they provide two versions of the truth $(2011,25)$. Linguistically, both channels pursue completely varying strategies in reporting the conflict. The choice of discourse often led to the emergence of two conflicting narratives of the truth. Barkho gives the example of AJE's 'Gaza fighters', as opposed to BBC's 'Gaza militants'; 'Palestinian rockets'/ 'militant rockets' and so on (ibid, 32). Re-lexicalising and over-lexicalising Palestinian actors, with regards to the BBC, were almost continuously accompanied with negative connotations and labels to remind the audience of their 'militancy' (Barkho 2010, 132). Such varying narratives of reality, argues Barkho, are the product of internal guidelines and ideologically intensive training, and not the work of journalists on the ground -'imposing a specific cultural depiction of one voice and a different one for the other' (ibid, 31). By doing so, journalists are made to adopt and resemble an 'organisational ideology' (ibid, 34) -while BBC represents an 'AngloSaxon' way of reporting, AJE 'places some Arabic and Islamic indexicals within a context that are akin to Arabs and Islamic culture and "alien" to what is the norm in the West' (ibid, 33).

This leaves us with key questions regarding the impartiality of news reporting: does the term 'impartiality' endow a rhetorical flexibility, subject to change in relation to public controversy, which acts as the product of an institutional discourse organised around a certain news story; or is impartiality a given value defined and identified under a certain organisation's guidelines and discursive practices? It also reminds us of the importance of critiquing the mediation of the occupation, turns our attention to the ways in which its mediation is becoming increasingly mediatic, and leaves us with questions concerning the relation between media and war.

\section{Mediatization}

As Denis McQuail has pointed out in a review article on the "mediatization of war", there is a great deal of evidence to support the claim that media war reporting in general is often inadequate, tending to be "...thin on explanation, extremely selective, oversimplified, implicitly biased for or against one or other party (only two sides can be handled), restricted in the frames within which information is placed, emphasizing spectacle and action, and disinclined to dwell on the death and destruction, especially as it affects non-combatants" (McQuail 2006, 115-116). Whether because of the chaotic and dangerous nature of war, the inevitable dependence upon biased sources of information, or limitations and pressures more typical to journalism and the particular medium involved, “...truly independent and truthful [war] reporting is largely unattainable” (McQuail 2006, 116).

In a general context in which state policies are produced in increasingly mediatized environments, and in which the media are more implicated than ever before in the 
political decision-making process (McQuail 2006, 115), it becomes even more important to establish clearly theorised, and empirically supported, "chains of reasoning" regarding the influence of the media on war, and/or vice versa (Livingstone 2009; McQuail 2006). Likewise, it is important to analyse the performative involvement and constitutive role of the media (Cottle 2006) in the conflict. McQuail argues that this entails acknowledging the ways in which the practices of media and war are becoming interlinked; in which war is becoming mediatized, and, by extension, in which media is becoming militarized.

The concept of 'mediatization' has, however, become a frequent and loosely applied, catch-all term (Deacon \& Stanyer 2014). Although Couldry (2008) has argued that 'mediation' is usually more useful than 'mediatization', and that it is often better to regard the two as complementary, we do not, in this special issue, reductively use the term 'mediatization' to identify a 'singular media logic' at play, but acknowledge the heterogeneity and non-linearity of transformations (Couldry 2008, 375). Nevertheless, in this particular instance, we do indeed focus on the ways in which media has become increasingly important as a tool of Israeli violence, as a means for Palestinians, both inside and outside of Gaza, to form a community, and for a counternarrative of the conflict to be produced. Our focus is not only on institutionalised forms of media or a one-way process, however, but on an 'unevenly, dialectical' process - that Silverstone (2002) calls 'mediation' - which involves the imbrication of media with politics and war, and the significance of this for the ways in which the occupation is conducted, experienced and represented.

Our use of the term, for this issue, at least, regards it as an "incomplete and still unfolding historical project" (Hjarvard, Krotz et al, in Livingstone 2009), distinct from the more common and quotidian practices of 'mediation', in that it potentially has a profound impact upon identity construction and social institutions (Hjarvard 2008). As well as highlighting the intensified and changing importance of media in the occupation of Gaza, we also use the term as a theoretical frame, inevitably and intricately linked to other theories, such as globalisation (Hjarvard 2008, 113). Adopting the mediatization framework - as a non-linear, multi-directional, multidimensional process, the degree and significance of which varies from one context to another (Strömbäck \& Esser 2014, 249) - raises normative questions about the relationship between media and, in this instance, the occupation of Gaza, without in itself being normative (Strömbäck \& Esser 2014, 248). Rather than limiting critique to just an interrogation of the influence of media coverage, for instance, addressing the mediatization of Gaza also asks more fundamental questions about 'how media and communications are related with certain sociocultural forms and their transformation(s)' (Hepp et al. 2015).

As a meta-process, it is less an empirical practice or process that can be investigated, than a theoretical approach to long-term and multiple processes of change (Hepp 2009, 140). Seeing it in terms of historical change, we also emphasise the increasing mediation of the occupation; that is, the changing role of media and its increasing importance to the representation and experience of the occupation, as well as the ways in which Israel occupies, and in which Gazans are occupied, in increasingly mediatized ways. Although there are negative aspects to this process, it is not necessarily and uniquely negative (Hjarvard 2008, 114). While the mediatization of the occupation entails changes to the form of violence enacted upon the inhabitants of 
Gaza, it also involves an expansion of the opportunities for interaction in virtual spaces and a differentiation of what people perceive to be real (Hjarvard 2008, 111).

Schulz (2004) proposes that there are four particular aspects to mediatization as a process of change: extension, substitution, amalgamation and accommodation. In the following articles, some or all of these aspects are suggested without any claim to a homogenous logic, one-way imposition or insistence on all four aspects being met in any particular account. While, for instance, social media have extended the limits of communication between young Palestinian refugees and those growing up in Gaza, the extent to which they have also substituted mainstream media news sources is worthy of investigation. And while the occupation of Gaza is no less military, territorial, physical or violent, engaging with the ways in which it is becoming also a 'mediated' (and therefore 'mediatized') or 'digital' occupation (Tawil-Souri 2012), necessitates an inquiry into the extent to which media and non-media aspects are amalgamated, and to which Gazans are obliged to accommodate to the occupation of their electromagnetic spectrum and the logic of a 'post-military withdrawal' occupation.

This issue seeks to investigate, therefore, the extent to which the various case studies presented demonstrate a process of mediatization; treating the topic of Gaza's mediatization as a point of analytical departure (Waisbord, 2013), rather than a presumed fact. Indeed, taken individually, these articles make no particular claim about the extent of mediatization; but taken as a whole, this issue interrogates the processual significance of various media to various aspects of the occupation, and the extent to which the occupation of Gaza can be said to have been mediatized.

\section{Mediatizing Gaza - the Articles}

Although the arrangement of the following articles in this particular order suggests a linear narrative of increasing mediatization - from discourse analyses of war reporting in mainstream media, to data visualisations of social media traffic - this is intended as nothing more than suggestion.

The issue begins with Nour Shreim's 'A Discursive Analysis of the Gaza Conflict of 2008-09: Provocation and Proportionality in War Reporting'. Her paper aims to provide a historical context to the recent events in Gaza by employing an interpretative discourse analysis of BBC World's coverage of Operation Cast Lead. By discursively and semantically analysing the news texts, the article develops two 'frames' of analysis to allow for a comparative dimension. These include Provocation, which looks at the motivations and rationale behind the ways in which the war was reported; and Proportionality, which looks at the depictions of casualties, the humanitarian condition and accusations of war crimes. The findings indicate that BBC World supported the Israeli narrative that the attacks were legitimate and rationalised, in the sense that Israel was retaliating to rockets fired by Hamas militants; however, when the proportionality of suffering and despair is compounded, the legitimacy attributed by BBC World to the Israeli army is eroded. 
In Rami Qawariq's contribution, “Victims vs Terrorists?' The Discursive Construction of Palestinians in Two Online Israeli Newspapers during the 2014 Gaza War', the author uses a Critical Discourse Analysis approach to investigate the representation of Palestinian social actors - both fighters/Hamas and civilians. Looking at the Jerusalem Post and Haaretz, his article critiques the linguistic choices and discursive strategies used in representing the examined groups. The study analyses the most frequent nominations used to refer to certain social actors. It shows how linguistic choices are ideologically and politically driven in this process of representation. Whilst the study attempts to highlight the linguistic and discursive differences present between the examined newspapers, it reveals that both newspapers tended to intensify the ideology of militancy and undermine the political or legitimate character of Palestinian factions and movements.

The subsequent article looks at how the Palestine Solidarity Movement in Ireland and the UK responded to the recent Israeli offensive on the Gaza Strip. Shadi AbuAyyash's article, 'The Palestine Solidarity Movement, Human Rights and Twitter', examines how major solidarity groups utilised social media platforms to highlight the alternative Palestinian narrative as an effort to counteract mainstream media's bias towards the Israeli government. The paper shows that Twitter was used as a tool to communicate with Palestinian activists around the world, to highlight the humanitarian situation in the strip, and emphasise the human rights violations that it entailed, as well as organising local supporting events. The author focuses on the ways in which the texts and images that accompanied the tweets posted by the groups all supported the movement's emphasis on a human rights discourse.

Moving on to the role media plays in the construction of self and community among third generation Palestinian refugees in Lebanon, May Farah begins her article, 'Palestinian Refugees and Mediated Connections to Palestine', by providing an historical account of media availability and access since the first refugees arrived in Lebanon in 1948. She then goes on to examine how Palestinian youth refugees rely on media to connect to Palestine and other Palestinians, and to stay-up-to date with realtime accounts from both the mainstream media and alternative sources. "Their understanding and knowledge of Palestine, therefore, comes from family stories, but increasingly from mediated constructions and representations". Her article combines an ethnographic approach with reception analysis, by conducting in-depth interviews with over 50 young adults in three refugee camps in Beirut. She argues that "it is through media that young Palestinians have learned of, and in most cases come to accept, the Occupied Palestinian Territories (OPTs) as the potential future independent Palestinian state (if they are granted the right of return), their community". This is a Palestine that does not encompass the original villages and towns of their grandparents, nor figure in the accounts of the stories they have been told of Palestine. She concludes that this generation's media access has provided a potentially greater connection to Palestine, despite the lack of first-hand experience and personal memories, as they have the stories, plus mediated access to present day Palestine.

Gary Bratchford's article, 'Operation Protective Edge 2014: Holding Language and Gaza Hostage', deals with the production of visibilities in Gaza. It begins with an examination of the ways in which language is used to frame Israel as a victim, and Gaza as a 'hostile entity', while a mainstream media focus on the most dramatic and 
fast-paced aspects of Israeli violence ignores the slower and more mundane ways in which life in Gaza is made unbearable. Turning to an account of 'unspectacular' disasters, such as power shortages and settlement routes, in the photographs of Gianluca Panella and Gaston Ickowicz, respectively, Bratchford then discusses critical documentary photography practice as a means of constructing a public visibility of social reality that would otherwise remain largely unseen. Similar to the ways in which social media and citizen journalism have brought the Palestinian experience to the attention of the global media audience, Bratchford argues, such photography deconstructs the dominant narrative and makes visible what is normally invisible; namely, the everyday experience of power shortages and settlements, the lack of autonomy and control, the slow violence of occupation, and the open-ended temporality of existence in Gaza.

The final article, from digital media theorist, Laila Shereen Sakr (also known as artist, VJ Um Amel), analyses a series of data visualisations of images tweeted under a set of hashtags linked to the 2014 assault on Gaza. In her article, 'A Virtual Body Politic on \#Gaza: The Mobilization of Information Patterns', she uses network graphs, topic modeling and hashtag analysis to produce these data visualisations, as well as interactive mosaics from audio and visual tweets, which create an immersive experience intended to make you "feel the bodies bloodied and maimed, bombed and broken, in photographs on social media in the hundreds of thousands". By comparing the information patterns and flows for each hashtag, the author demonstrates the differences that emerge between different online communities, and develops an account of a virtual body politic. Focusing in particular upon public sharing among global witnesses, and drawing mainly upon the work of Katherine Hayles, she sees this as an "abstraction of people who exchange ideas publicly online about the governance of an authority through visual representations of bodies as a site of political control".

The issue closes with 'The Digital Occupation of Gaza: An Interview with Helga Tawil-Souri'. In this interview, Simon Dawes asks Helga Tawil-Souri about the significance of digital technology to the Israeli occupation of the Gaza Strip. Her work examines the progressive digitalisation of the Israeli occupation and Palestinian efforts at resistance, and critically interrogates the extent to which they are technologically facilitated. She also discusses whether Israel's military, infrastructural, territorial as well as technological control over Gaza, which limits and restricts Gazans within a given boundary, can be seen as instances of settler colonialism and occupation. The interview focuses on what Tawil-Souri calls the 'digital occupation' of Gaza, which, she argues, furthers a neoliberal agenda that exacerbates the Palestinian reliance on Israel whilst enhancing Israel's infrastructural and territorial confinement of the Strip. 


\section{References}

Al-Jazeera English (2011), 'Gaza Lives On' Al-Jazeera World (Nov. 16 ${ }^{\text {th }}$ 2011). Available at:

http://www.aljazeera.com/programmes/aljazeeraworld/2011/10/20111019124 914593989.html [Accessed Feb. 1st, 2012]

Al-Jazeera English (2014), 'Gaza Farmers Struggle in War aftermath' (Oct. $7^{\text {th }}$ 2014). Available at: http://www.aljazeera.com/news/middleeast/2014/10/gazafarmers-struggle-war-aftermath-20141075578186995.html [Accessed Jan 30, 2015]

Amnesty International (2009) Israel/Gaza - Operation 'Cast Lead': 22 Days of Death and Destruction. Amnesty International Publications. Available at: http://www.amnesty.org/en/library/asset/MDE15/015/2009/en/8f299083-9a744853-860f-0563725e633a/mde150152009en.pdf [Accessed 13th Feb. 2012]

Amnesty International (2010) 'Suffocating Gaza -the Israeli Blockade's Effects on Palestinians' Amnesty International (June $\left.1^{\text {st }} 2010\right)$. Available at: http://www.amnesty.org/en/news-and-updates/suffocating-gaza-israeliblockades-effects-palestinians-2010-06-01 [Accessed Feb. 1st 2012]

Amnesty International (2014) 'Israeli forces displayed 'callous indifference' in deadly attacks on family homes in Gaza' (November $\left.5^{\text {th }} 2014\right)$. Available at: http://www.amnesty.org/en/news/israeli-forces-displayed-callous-indifferencedeadly-attacks-family-homes-gaza-2014-11-05 [Accessed Jan. 30th 2015]

Barkho, L. (2010) 'The BBC'S Discursive Strategy and Practices vis-à-vis the Palestinian-Israeli Conflict'. In Language and Journalism 9 (2): 278-294.

Barkho, L. (2011) 'The Discursive and Social Paradigm of Al-Jazeera English in Comparison and Parallel with the BBC' in Communication Studies 62 (1): 23-40.

Barkho, L. and Richardson, J.E. (2010) 'The impact of BBC production strategies on news discourse' in American Communication Journal, Volume 12.

BBC News (2010) 'Guide: Gaza under Blockade' BBC News (July $\left.6^{\text {th }} 2010\right)$. Available at: $\underline{\text { http://news.bbc.co.uk/1/hi/world/middle east/7545636.stm }}$ [Accessed 17th March, 2012]

BBC News (2014a) 'Gaza-Israeli Conflict: Is the fighting over?' (August 26 ${ }^{\text {th }}$, 2014). Available at: http://www.bbc.co.uk/news/world-middle-east-28252155 [Accessed February 1st, 2015]

BBC News (2014b) 'Abducted Israeli teens found dead near Hebron' (June $30^{\text {th }}$ 2014). Available at: http://www.bbc.co.uk/news/world-middle-east28097164 [Accessed February 1st, 2015] 
Bell, B. (2009) 'Counting Casualties of Gaza's War' BBC News (Jan. $28^{\text {th }}$, 2009). Available at: http://news.bbc.co.uk/1/hi/world/middle east/7855070.stm [Accessed February 1st, 2012]

Chanan, M. (2014a) 'Behind the News from Gaza', Putney Debater blogpost. Available at: http://www.putneydebater.com/behind-the-news-from-gaza/ [Accessed July 29 ${ }^{\text {th }}, 2014$ )

Chanan, M. (2014b) 'Loneliness of the Long Distance Propagandist', Putney Debater blogpost. Available at: http://www.putneydebater.com/loneliness-ofthe-long-distance-propagandist/ [Accessed August 1 ${ }^{\text {st }}, 2014$ )

Cottle, S. (2006) Mediatized Conflict. Maidenhead: Open University Press

Couldry, N. (2008). 'Mediatization or mediation? Alternative understandings of the emergent space of digital storytelling'. New Media \& Society, 10(3), 373391.

Deacon, D. \& James Stanyer (2014) 'Mediatization: key concept or conceptual bandwagon?' Media, Culture \& Society , 36(7): 1032-1044

Erlanger, S. and Kershner, I. (2014) 'Israel and Hamas Trade Attacks as Tensions Rises' The New York Times (July $8^{\text {th }}$ 2014). Available at: http://www.nytimes.com/2014/07/09/world/middleeast/israel-steps-upoffensive-against-hamas-in-gaza.html? $\quad r=1$ [Accessed_Feb 1st, 2012]

Food and Argiculture Organization of the United Nations (2014), 'Gaza: Damage to agriculture will have long-lasting effects' (August 14, 2014). Available at: http://www.fao.org/news/story/en/item/240924/icode/ [Accessed Jan. 25 2015$]$

Gaber, I. Seymour, E. and Thomas, L. (2009) 'Review Commentary: Is the BBC biased? : The Corporation and the coverage of the 2006 Israeli -Hezbollah war' in Journalism 2009 10: 239

Goldberg, J.J. (2014) 'How Politics and Lies Triggered an Unintended War in Gaza' The Jewish Daily Forward (July $10^{\text {th }} 2014$ ). Available at: http://forward.com/articles/201764/how-politics-and-lies-triggered-anunintended-war/?p=all\#ixzz374CPB51T [Accessed Jan. $25^{\text {th }} 2015$ ]

Grim, R. (2014) 'Tariq Abu-Khdeir Was Beaten By Israeli Police' Huffington Post (July $7^{\text {th }}$ 2014). Available at:

http://www.huffingtonpost.com/2014/07/07/tariq-abu-khdeirbeaten $\mathrm{n}$ 5565266.html [Accessed Jan. 26th, 2015]

Hepp A (2009) 'Differentiation: mediatization and cultural change'. In: Lundby K (ed.) Mediatization: Concept, Changes, Consequences. New York: Peter Lang

Hepp, A., Stig Hjarvard and Knut Lundby (2015) 'Mediatization: theorizing the 
interplay between media, culture and society', Media, Culture \& Society, 0163443715573835, first published on February 17, 2015

Hjarvard, S. (2008). 'The Mediatization of Society. A Theory of the Media as Agents of Social and Cultural Change.' Nordicom Review 29 (2): 105-134.

Kuntsman, A. and Rebecca L. Stein (2015) Digital Militarism: Israel's Occupation in the Social Media Age, Stanford: Stanford University Press

Livingstone, S. (2009) 'On the mediation of everything'. ICA Presidential address 2008. Journal of Communication, 59(1), 1-18.

Loughborough University Communications Research Centre (2006) 'The BBC's Reporting of the Israeli-Palestinian Conflict (August 12005 - January 31 2006), Research Report. Loughborough: Loughborough University

McQuail, D. (2006) 'On the mediatization of war'. The International Communication Gazette, 68(2), 107-118

Percival, J. (2008) 'Israel launches deadly Gaza attacks' The Guardian (Dec, $\left.27^{\text {th }} 2008\right)$. Available at:

http://www.guardian.co.uk/world/2008/dec/27/israelandthepalestinians

[Accessed Feb 1st 2012]

Philo, G. and Berry, M. (2004) Bad News from Israel, London: Pluto Press

Philo, G. and Berry, M. (2006) 'Bad News and Public Debate about the IsraelPalestine Conflict', in Poole, E. and Richardson J.E. (eds.) Muslims and the News Media, New York: I.B. Tauris \& co. Ltd.

Philo, G. and Berry, M. (2011) More Bad News from Israel, London: Pluto Press

Richardson, J. E. (2004) (Mis)Representing Islam: the racism and rhetoric of British Broadsheet newspapers. Amsterdam: John Benjamins

Richardson, J. E. and Barkho, L. (2009) 'Reporting Israel/Palestine: the verbal and visual rhetoric of BBC journalism'. In Journalism Studies 10 (5): 594-622.

Roy, S. (2007) Failing Peace: Gaza and the Palestinian-Israeli Conflict. Pluto Press.

Schulz, W. (2004). 'Reconstructing mediatization as an analytical concept'. European Journal of Communication, 19(1), 87-101

Silverstone, R. (2002) 'Complicity and Collusion in the Mediation of Everyday Life', New Literary History 33(5): 745-64

Sobelman B. (2014) 'Rockets Salvos from Gaza Prompt Israeli military strikes' Los Angeles Times (July $8^{\text {th }}$ 2014). Available at: 
http://www.latimes.com/world/middleeast/la-fg-israel-military-operationhamas-20140708-story.html [Accessed Jan. 27th 2015].

Strömbäck J and Esser F (2014) 'Introduction: making sense of the mediatization of politics'. Journalism Studies 15(3): 243-255

Tawil-Souri, H. (2012) 'Digital Occupation: Gaza's High-Tech Enclosure', Journal of Palestine Studies, 41(2), 27-43

The Guardian (2014) 'Israel accused of war crimes during campaign in Gaza' (Nov. $5^{\text {th }}$ 2014). Available at:

http://www.theguardian.com/world/2014/nov/05/israel-accused-war-crimesgaza--amnesty-international [Accessed Jan. 27th 2015]

United Nation (2014) 'Erosion of Gaza's economy accelerates amidst Israeli military operations, ongoing blockade UN' United Nations News Centre (Sept.

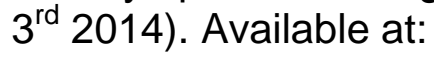

http://www.un.org/apps/news/story.asp?NewsID=48631\#.VMe6uXDkfB4 [Accessed Jan. 30 ${ }^{\text {th }}, 2015$ ]

Waisboard, S. (2013). 'A Metatheory of Mediatization and Globalization?' Journal of Multicultural Discourses, 8 (3): 182-189.

Wolfsfeld, G. (2006): A Review of: "Bad News from Israel, by Greg Philo and Mike Berry", Political Communication, 23 (4): 475-476

Nour Shreim is a $\mathrm{PhD}$ graduate from the Department of Social Sciences at Loughborough University and is currently a Research Manager at Livestation Ltd. Her research focuses on discourse, news reporting and reception, with a particular interest in Arab media.

Email: $\underline{\text { n.shreim1@gmail.com }}$

Simon Dawes is the Editor of Networking Knowledge - the Journal of the MeCCSA $P G N$, editorial projects \& website manager of Theory, Culture \& Society and Body \& Society, and professeur contractuel at Université Paul Valéry - Montpellier 3, France. His research revolves around issues of media theory, history and regulation.

Email: simondawes0@gmail.com 